\title{
Morphological Adaptation of English Loanwords in Twitter:
}

\section{Educational Implications}

\author{
Fatimah Dashti ${ }^{1} \&$ Abdulmohsen A. Dashti ${ }^{2}$ \\ ${ }^{1}$ Kuwait University, Department of Curriculum\& Instruction, Kuwait \\ ${ }^{2}$ PAAET, Department of English. Kuwait \\ Correspondence: Abdulmohsen A. Dashti, PAAET, Department of English. Kuwait
}

Received: June 5, 2017

Accepted: June 18, 2017

Online Published: June 23, 2017

doi:10.5430/ijhe.v6n3p231

URL: https://doi.org/10.5430/ijhe.v6n3p231

\begin{abstract}
The influx of English borrowed items into Kuwait has recently considerably increased, driven by both linguistic and extra-linguistic factors, mainly through new electronic media, and direct contact with the donor language. Kuwaitis, especially, the new generation heavily make use of English loanwords in mobile devices applications such as Twitter, Instagram, Facebook, Snapchat, and others. It is significant to note that a recipient language (in this case Kuwaiti Arabic, KA henceforth) discloses different morphological and phonological features that affect English loanwords. 400 hundred tweets tweeted by young Kuwaitis were captured and then, qualitatively analysed. This paper investigates the morphological adaptation of English loanwords as used by Kuwaitis in twitter. Results indicate that Kuwaitis heavily use and adapt English loanwords morphologically in twitter and in everyday speech. Significant educational implications were collected as well through interviewing 50 students.
\end{abstract}

Keywords: Twitter, linguistics, Morphological adaptation, Educational implications, English Loanwords

\section{Introduction}

English is growing as a language of technology all over the Arab world. In Kuwait, English is the language of trade, technology, fashion and most importantly, of prestige (Dashti, 2015; Dashti \& Dashti, 2015; Dashti \& Dashti, 2016)). We know from literature that any recipient language discloses different morphological and phonological features that affect loanwords (Al-Athwary, 2016; Jarrah, 2013; Oh \& Kim, 2012; Khan \& Bukhari, 2011; Islam, 2011; Alomoush, \& Al faqara, 2010; Amara 1999). Linguistic adaptation of English loanwords in different countries were tackled from a semantic (Al-Bader 2016)), lexical (Amara, 1999) phonological (Jarrah, 2013; Khan \& Bukhari 2011; Abdullah and Daffar 2006; La Charité \& Carole 2005; Davidson, \& Noye, 1996), and morphological (Oh \& Kim 2012; Islam, 2011) perspectives. The database of most studies came from direct observation, newspapers, the researchers' own intuition, and interviews with different informants. A few studies examined linguistic adaptation in the media (See Al-Athwary, 2016; Goldstein, 2012; Tatsioka (2008). However, there has been no trace of studies examining morphological adaptation of English loanwords in Kuwaiti media. Hence, this study is concerned with exploring this issue.

\section{Literature Review \& Theoretical Framework}

"Established loanwords" (Romaine, 1989: 61) are "accepted, recurrent, widespread and collective. They are used "regularly and are permanently present and established in the recipient language's monolingual environment" (Hafez, 1996: 2). When words are borrowed from other languages, these words are phonologically and morphologically adapted according to the sound and morphology of the recipient language (Kenstowicz, 2003, La Charite 2005, Alder 2006, Davidson and Rolf 1996). Kachru (1994) proposes two hypotheses about the motivation for lexical borrowing in languages: the deficit hypothesis and the dominance hypothesis. Kachru (ibid:139) states that "the deficit hypothesis presupposes that borrowing entails linguistic gaps in a language and the prime motivation for borrowing is to remedy the linguistic deficit, especially in the lexical resources of a language". This entails that people borrow lexical items from other languages because there are no equivalents in the recipient language. The dominance hypothesis presupposes when two cultures come into contact, the direction of culture learning and subsequent word-borrowing is not mutual but from dominant to the subordinate. This is not necessarily done to fill the gaps. Many words are borrowed even though they have their native equivalents because they seem to have prestige. At the morphological level, some words become out of use whereas novel words are added to the language because of different processes. 
Communicating online is almost like amid-ground between spoken language and written language. The term used for this is 'written-speak', 'spoken-writing' or 'text-speak'. Gruppetta (2016) refers to it as a 'language-disabled generation'. For space limit, only a few studies that dealt with morphological adaptation in the media will be summarised below.

Oh \& Kim (2012) investigated adaptation of the English plural suffix into Korean in Google searches. They claimed that the morphology of a borrowed word should be referred to in calculating sound mappings in loanword adaptation and that the phonetic information of the loanword still influences loan adaptation. The adaptation of the allomorphs $/ \mathfrak{t}$, db/into a single sound in Korean supported their argument. Al-Athwary, (2016) investigated the semantics of English loanwords in Arabic media language by analysing loanwords from Arab Gulf states newspapers. The analysis revealed that technical and scientific English loanwords in Arabic media are found ranking much higher (9\% - 18\%) than nontechnical loanwords $(1 \%-8 \%)$. Factors like need, semantic similarity, and factors of social and psychological considerations (e.g. prestige, taboo) seem to be the potent factors at interplay in semantic change. Al-Athwary's (ibid) study claimed that the problem of synonymy lies in those loanwords that have "Arabic equivalents" in the language. Goldstein (2012) who investigated the use of English loanwords in Japan's television program, magazines, and men's and women's fashion claimed that English used in Japanese media is mainly decorative rather than communicative. The study highlighted a tremendous number of grammatical mistakes in the use of loanwords. Tatsioka (2008) who investigated the use of English loanwords in the Greek TV as well as peoples' attitudes claimed that there was a general recognition of the existence of the use of loanwords in the Greek media and that the majority expressed negative attitudes as it is affecting the Greek language. The study also claimed that the Greeks used loanwords as a sign of prestige. Felonik (2013) examined 247 loanwords extracted from Ukrainian weekly and daily newspapers as well as Ukrainian youth forums online, looking at gender as a sociolinguistic parameter. The research aimed at finding out what motivates formal assignment of a certain gender to Ukrainian loanwords. Results showed that the inflection system is essential in assigning gender to English words borrowed by Ukrainian. Bahumaid (2015) analysed 125 English loanwords in Hadhrami Arabic from oral and printed sources. The study looked at pluralization, gender assignment and verb patterning. Among the results, most loan compound nouns, the two elements that make up the compound noun have been contracted into one word or the second element of the compound has been emitted. As for the pluralization, regular masculine singular nouns that end in a consonant are pluralized by the addition of the morphological inflection /-a:t/. As to verb patterning, English verbs have been adapted to native patterns. Verbs that consist of a root of three or four consonants, vowels are inserted between them e.g., /baraf/ 'to brush'; /kansal/ 'to cancel'. The results also indicated that loanwords served the purpose of filling lexical gaps in the dialect.

\subsection{The Scope and Purpose of the Study}

As stated above, there has been no trace of morphological studies examining the issue of linguistic adaptation of English loanwords in Kuwait. Furthermore, literature does not show any study of examining morphological adaptation of English loanwords as they appear in twitter in the Arab world or the Arab peninsula. Therefore, the study is hoped to add additional novel data to the existing literature.

\section{Methodology}

\subsection{Data Collection \& Tools}

The main source of the data corpus of this study came from examining 400 hundred tweets tweeted by young Kuwaitis most of whom followed the researchers' twitter accounts. All tweets were captured and then, qualitatively analysed. In addition, 25 males and 25 female students in the colleges of education were informally interviewed. The reason of the interviews is not only to verify the tweets' analysis, but also to identify similar morphological adaptation in their speech and to gain some educational implications. For the sake of gaining spontaneous speech, the researchers met the students in groups during office hours. The students were told that the researchers are carrying out a research on the importance of social media. They were not told the real purpose of the research. A total of 102 English loanwords were collected. The students then were asked about their attitudes towards the use of loanwords in social media and in everyday speech and if that would affect their native language.

\subsection{Research Questions}

The paper aims to answer the following questions:

1. What mechanisms are employed by Kuwaitis to morphologically adapt English loanwords?

2. What educational implications does the use of English loanwords denote? 


\section{Discussion \& Data Analysis}

Analysis will start by first examining the morphological adaptation mechanisms followed by an examination of the interviews' results.

The analysis touched upon the following morphological features:

- Pluralisation of loanwords by suffixation.

- Prefixing the Kuwaiti definite article /Ril/ to English loanwords.

- Adaptation of English personal pronouns.

- Prefixing demonstratives to English loanwords.

- Using negatives with English loanwords.

- Prefixing prepositions to English loanwords.

- Utilization of Conversion

- Prefixing collectives to English Loan nouns.

- Using Clipping as a morphological process.

For space limit, three tweet examples of each feature will be provided.

\section{Pluralisation of loanwords by suffixation.}

The English plural morpheme (s) has three different allophones, namely, [s], [z] or [əz]. Morphologically speaking, all single nouns in English, with few exceptions are pluralized by suffixing one of these allophones to the single noun depending on the stem-final segment. The KA plural system has mainly [a:t] suffixed to the noun which is frequently used with loanwords as shown below:

\section{Tweet 1}

/ilkominta:t

the comments

$$
\begin{array}{lllll}
\text { maraĐ atwaqa } & \text { Illi } & \text { ga:Yid } & \text { jSlqu:n } & \text { jahha:j/ } \\
\text { disease I believe } & \text { those } & \text { stay } & \text { comment } & \text { children }
\end{array}
$$

The comments are horrible: I believe that those who are commenting are young children.

\section{Tweet 2}

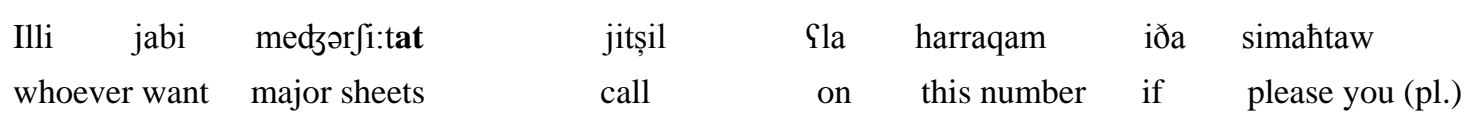

Whoever wants to get course work major sheets, please call this number.

\section{Tweet 3}

$\begin{array}{llll}\# & \text { ilgru:ba:t_ } & \text { bi } & \text { twitər (a hashtag title) } \\ \text { hashtag } & \text { the groups } & \text { in } & \text { twitter }\end{array}$

The groups in twitter

\section{Prefixing the Kuwaiti definite article /2il/ to English nouns.}

The KA definite article is / $\mathrm{Pil} / /$ and mostly contracted to /l/. It is always prefixed to the noun and adjective modifying it. In borrowed loanwords, the KA definite article / $\mathrm{Pil} /$ or the contracted /1/ is always prefixed to English borrowed loanwords. For example:

\section{Tweet 4}

/Pilloke Sin wala Slek amor the location and no on you order

The location, if you don't mind.

\section{Tweet 5}

$\begin{array}{lcll}/ \text { min simaS } & \text { 2ilvojs } & \text { hagik } & \text { ixtaraS } \\ \text { when (he) listen } & \text { the voice } & \text { yours } & \text { scared }\end{array}$


When he listened to your voice, he got scared.

Tweet 6
/PilmaSna
Ihaqi:qi 1 Pilanfolo
jaßni
iglob
wajhik
amma lblok
the meaning
the true for the unfollow
mean
upside down face your or
the block
The true meaning of 'unfollow' is that you either get out of my face (stop harassing me)
or else I'll block your account.

\section{Adaptation of English possessive pronouns.}

Possessive pronouns (my, your, his, her, our, their) are used to indicate ownership of something. In

KA, these take the form of suffixes; they are attached to the noun that's owned. For example:

\begin{tabular}{|c|c|c|}
\hline 1sing poss. $-\mathrm{i}$ & /Șu:rti/ & my photo \\
\hline $2 \mathrm{~ms} . s n g \quad-i k$ & /rab?ik/ & your friends \\
\hline 2 f. sng. -itf & /mifa:ti:hitg/ & your keys \\
\hline 3 m.sng. -a & /ixta/ & his sister \\
\hline 3 f.sng. -ha & /sajja:ratha/ & her car \\
\hline $1 \mathrm{pl}$. & /firi: dzna/ & our neighborhood \\
\hline 2pl. -kum & /imtiћa:na:tkom/ & your exams \\
\hline 3pl. -hum & /rifi: dzhom/ & their friend \\
\hline
\end{tabular}

Dashti (2013) introduces a new personal pronoun that Kuwaitis resort to, namely, /ma:1/ meaning "belong to". The following table shows /ma:1/ conjugations in KA:

$\begin{array}{lll}\text { /ma:l/ preceded by a masculine noun } & \text { /ma:l/ preceded } & \text { ma:lti } \\ \text { ma:li } & \text { belong to me } & \text { ma:lt } \varepsilon \\ \text { ma:le } & \text { belong to him } & \text { ma:leth } \varepsilon \\ \text { ma:lhe } & \text { belong to her } & \text { ma:letn } \varepsilon \\ \text { ma:ln } \varepsilon & \text { belong to us } & \text { ma:letkom } \\ \text { ma:lkom } & \text { belong to you } & \text { ma:lethom } \\ \text { ma:lhom } & \text { belong to them } & \end{array}$

Our data of English loanwords showed the following:

Tweet 7

kalfarna faxarna (Hashtag title)

culture our pride us

Proud of our culture.

Tweet 8

/Pinzen Pilli gaCid jihakir inistigra:mi finu tabi/

ok the one sitting hacking Instagram my what want you

Ok, whoever busy hacking my Instagram, what do you want (what's your problem)?

Tweet 9

/haðela ana naqalthom $\quad \min 1$ watsab ma:li/

these I transferred them from the WhatsApp my

I have transferred these from my WhatsApp.

\section{Prefixing demonstratives to English loanwords}

Holes (2015:85) states that Kuwaiti Arabic displays the following demonstratives: 
Proximal m. (ha:)ða Proximal f. (ha:)ði Proximal pl. (ha)ðəla

Distal m. (ha)ðak Distalf. (ha)ðik Distal pl. (ha)ðəlak

Whenever demonstratives appeared in our data they are always followed by the definitive

Article (il), but mostly realized as (al). Our data showed the following examples:

\section{Tweet 10}

/rah ja?dzibik halklip/

will admire you this clip

You will admire this clip

\section{Tweet 11}

/la: jţu:fkơm halmən $\int \mathrm{in} /$

no miss you (pl.) this mention

Don't miss this mention.

\section{Tweet 12}

\begin{tabular}{|c|c|c|c|}
\hline & $\begin{array}{c}\text { nabi } \\
\text { we want }\end{array}$ & $\begin{array}{l}\text { da?mkum } \\
\text { support your }\end{array}$ & $\begin{array}{l}\text { ћaq } \\
\text { for }\end{array}$ \\
\hline
\end{tabular}

Please we want your support for this Podcast.

\section{Using negatives with English loanwords}

KA has three negative elements: la:, ma:, and mu:. According to Johnstone (1967) ma: in KA negates forms of the personal pronouns. Holes (2015) believes that ma: is used with indicative verbs, whereas la: is used with imperatives, opatatives, all coordinated negatives, for categorical negatives, emphatic sense, and in subordinated clauses. AL-Salem (2012) stated that mu: is a constituent negation. She (ibid) also added jer as a negation particle.

\section{Tweet 13}

$\begin{array}{lrrl}\text { mute.. } & \text { ?afan } & \text { ma: aminfin } & \text { iða niset :) } \\ \text { mute } & \text { so } & \text { no I mention } & \text { if forgot I }\end{array}$

Mute, so I wouldn't mention if I forget (Here, in addition to inserting the Kuwaiti Arabic ma: before the noun 'mention', the noun has also been used as a verb indicating future.

\section{Tweet 14}

\begin{tabular}{|c|c|c|c|c|}
\hline $\begin{array}{l}\text { aћaðirkum la: tratwitu:n } \\
\text { warn you (pl.) (neg) retweet (pl) }\end{array}$ & & $\begin{array}{l}\text { twi:ta } \\
\text { tweet a }\end{array}$ & $\begin{array}{l}\text { la: jsiћbu:nkom } \\
(\text { neg) they drag you (pl) }\end{array}$ & $\begin{array}{l}1 \text { dzara:im } \\
\text { the criminal }\end{array}$ \\
\hline laliktronija/ & & & & \\
\hline
\end{tabular}

I warn you. Don't retweet any tweet (be careful when retweeting others); otherwise you will be questioned by the Electronic Criminal Department.

\section{Tweet 15}

/le ma: $\quad$ kajjafta... ikilha $\quad$ lhi:n why (neg) (you) cashed it... you eat it now

why haven't you cashed it? Now it's your problem.

\section{Prefixing prepositions to English loanwords}

Kuwaiti Arabic embraces a number of prepositions such as fi:, bi, li, wijja, hagg, Ma?a, ?ala, ?an, and many others. Here are a few examples from our data: 
Tweet 16

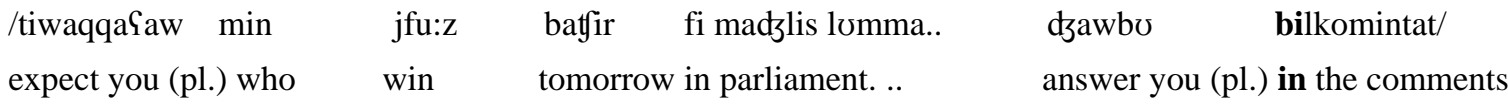

Who do you expect to win (as members) in the parliament tomorrow? State your answers

In the 'comment' box.

Tweet 17

$\begin{array}{cclll}\text { /Pilasma:? } & \text { PilmistaSara fissofal mi:dja laha } & \text { adzinda:t xaŞa/ } \\ \text { the names } & \text { the borrowed } & \text { in the social media have } & \text { agendas special }\end{array}$

The fake accounts in the social media have special agendas.

Tweet 18

/hiţ bja:na:tik Sala halwəb/

upload data your on this web.

Upload your personal data on this web.

\section{The Utilization of Conversion}

Conversion is a word formation process involving the creation of a word (of a new word class) from an existing word (of a different word class) without any change in form. In English, we encounter nouns like 'the can', 'the trash', and 'the file' are changed to 'to can', to trash', and 'to file'. However, in Semitic languages, of which Arabic is one, the process often involves changes of internal vowels, and the form as well.

\section{Tweet 19}

/ Ya:di aminshin dika:triti?

ok I mention professors my

Is it Ok to mention my professors? (the noun 'mention' has been changed into a verb).

\section{Tweet 20}

/ma: jiðbahni illa lli jibatwin ben issaja:ra:t/

(negative) kill me only that he goes between between the cars

What most bothers me is the one who zigzags while driving. (the English proposition 'between' has been used as a verb with a change in both form and internal vowels).

Tweet 21

/la:zim adif Gala 1 blokd akawnt/

must I enter on the bloked akawnt

I must enter the blocked account. (suffixing the past participle inflectional bound morpheme -en,

Hence, using the verb 'block' as an adjective)

Another mechanism Kuwaitis adopt as a process of conversion is to precede the noun with a KA verb for the sake of verbalization.

Tweet 22

/la: tla?wizni rah a?ţi:k blok/

don't bother me will I give you block

Don't bother me. I will block your account.

\section{Tweet 23}

/aswwi ritweet yaȘub.. ma: bi/

I do retweet by force.. don't I want

Do you want me to retweet by force? I don't want (I am not going to do it). 


\title{
8. Prefixing collectives to English Loan nouns.
}

kil "each, every, all" is used as a collective by Kuwaitis. Variants of kil are killəbə and killəbu:hum. Our data furnished the following examples:

\section{Tweet 24}

/kilil akkawntat momilla min Șiḑ/
all the accounts boring from truth

All the accounts are (really) boring.

\section{Tweets 25}

\section{/Pilkomenta:t killibuha ljom San irrjaĐa \\ the comments all of them today about sports \\ All comments today are about sports.}

\section{Using Clipping as a morphological process}

Clipping is the process of forming a new word by dropping one or more syllables from a polysyllabic word, such as cell from cellular phone. A clipped form generally has the same denotative meaning as the word it comes from, but it is regarded as more colloquial and informal. On occasion, a clipped form may replace the original word in everyday usage — such as the use of piano in place of pianoforte.

\section{Tweet 26}

/Mabru:k ista:d fora:d. kil gru:bat lwats titkalam Sanik

congratulations Mr. Foad. all groups the whats talk about you

Congratulations Mr. Foad (Personal name). All WhatsApp groups are talking about you.

\section{Tweet 27}

\author{
/kil faj mawdzu:d fi lsna:b/ \\ Everything available in the snap \\ Everything is in the snap(chat)
}

\section{Interviews}

During the interviews, the students deployed a tremendous number of loanwords while expressing their views about social media. When asked how social media, mainly twitter, may influence their native language, they came up with interesting data. Some claimed that although they write in KA in twitter rather than SA, that does not negatively influence their SA. They claimed that most of the loanwords they use is to fill in a language gap. Even though Arab educationalists try to Arabize social media language, Arabization does not appeal to them as young people. They believed that twitter, is a reliable source of novel vocabulary and idioms. They do realize that English is an international language and that loanwords are used in fashion, food industry programs, TV, fancy restaurants, etc. Accordingly, they find it prestigious to use English either in speech or in writing. This corresponds with Kay (1995: 74) who mentioned "Loanwords are often associated with a sophisticated, Western lifestyle, and may be used in place of Japanese words of equivalent meaning because of their foreign appeal. Their modem image often makes them preferable to domestic equivalents, where these exist". It is worth mentioning that the use of English loanwords in Kuwait is both a class marker and an age marker. They are used across all society by the young generation, not as a separate language, but as part of the native language (Kachru 1994). They also claimed that English loans can be used to express feelings or describe situations which may be difficult to talk about in Arabic. Some claimed that Twitter develops their English language writing abilities and that the use of loanwords in everyday use have become part of their habits. Some claimed that Arabic is associated with tradition, home, religion, culture, school, arts and social sciences, whereas English is symbolic of modernity, higher education, commerce, science and technology. An interesting justification by our students was the idea of the deterioration in all aspects of life in Kuwait such as sports, TV shows, education. Because of such deterioration, they tended to search for the western culture. Doing that, the adoption of English loanwords in speech and writing became quite normal. Some believed that the use of loanwords, even though they adapt it to their phonological and morphological system helps increase the size of their lexicon. They feel happy that unfamiliar words are constantly being added. In addition, some loanwords are unavoidable, they said. 
Other respondents, on the other hand, expressed totally an opposite opinion. They claimed that twitter affects negatively their standard Arabic where they gradually become less aware of their writing, and hence, do not pay attention to writing errors they commit. Even though some twitter accounts tend, occasionally, to correct few errors, yet they become an object of ridicule as followers ask them to focus on the content, not the language. Nowadays, many children, they claim use WhatsApp to communicate with their classmate. They commit terrible writing mistakes and there is no one there to correct them. Consequently, errors continue till they grow up. Some claimed that their writing in Arabic or English is deteriorating because of their excessive use of text messages and twitter where they resort mainly to abbreviations and emoticons. This is effecting their grammar and spelling in the first place. Some said that they found themselves using more loanwords in their speech than KA equivalents. Often, they were scolded by their parents and grandparents. Others said that they get frustrated when they find out that their English writing is full of spelling mistakes and whenever they write in CA, their writing ends up with a mixture of slang and loanwords. Some claimed that loanwords are quite destructive; Sometimes “we hear some words frequently used by anyone, but we don't know what it means". Finally, some claimed that Arabic equivalents are available in KA, so there is no need to resort to loanwords.

The analysis above corresponds with Hafez (1996) that loanwords are accepted, recurrent, widespread and collective and with Kenstowicz (2003), La Charite (2005), Alder (2006), Davidson and Rolf (1996) that loanwords are usually phonologically and morphologically adapted according to the sound and morphology of the recipient language. It also tallies with Kachru 's deficit hypothesis that borrowing entails linguistic gaps in a language (Kachru 1994, Bahumaid 2015). The analysis also matches with studies of Al-Athwary (2016), Kay (1995), Goldstein (2012) and Tatsioka (2008) that loanwords are used as a sign of prestige and with Kachru (1994), and studies of Al Btoush (2014) that they are used across all society by the young generation, not as a separate language, but as part of the native language and they have become part of their habits. It also corresponds with Al-Athwary, (2016) that Arabic equivalents are available in KA and with Tatsioka (2008) that people expressed negative attitudes as it is affecting the Greek language.

Linguistically, the above analysis corresponds with studies of Oh \& Kim (2012) and Bahumaid (2015) regarding the plural morpheme suffixation, and Bahumaid's (2015) study of verbalisation. More studies are needed to explore the adaptation of other linguistic features in the media.

\section{Conclusion}

This paper investigated the morphological adaptation of English loanwords as used by Kuwaitis in twitter. 400 hundred tweets were transcribed, examined, and qualitatively analysed. In addition, 50 students from colleges of education were interviewed to verify the analysis' results and to gain some educational implications. Through examining 9 morphological adaptation features, the results indicated that Kuwaitis heavily adapt loan words morphologically in twitter and in everyday speech. They adapt those features to correspond with KA phonological and morphological realizations. The students through the interviews expressed both positive and negative attitudes. It is hoped that this paper has explored a new sociolinguistic behaviour in Kuwait and has added information to the existing literature.

\section{References}

Abdullah, A. B. and Daffar, A. M. (2006). English Loan Words in the Spoken Arabic of the Southern Part of Iraq: a Sociolinguistic Study. Journal of the College of Arts. University of Basrah No., (41), 19-36.

Adler, Allison N. (2006). Faithfulness and perception in loanword adaptation: a case study from Hawaiian. Lingua, 116, 1024-1045. https://doi.org/10.1016/j.lingua.2005.06.007

Al-Athwary, Anwar. A. H, (2016). The semantics of English Borrowings in Arabic Media Language: The case of Arab Gulf States Newspapers. International Journal of Applied Linguistics \& English Literature, 5(4), July 2016.Pp. $110-121$

Al Btoush, M. A. (2014). English Loanwords in Colloquial Jordanian Arabic. International Journal of Linguistics, $5(2)$.

Alomoush, O. I; Al faqara, W. M. S. (2010). Loanwords into Jordanian Arabic. Journal of Language \& Literature; (20780303); May2010, (2), 27.

Al-Salem, E. G. (2012). Negation in Standard and Kuwaiti Arabic. Unpublished MA thesis. University of Illinois at Urbana-Champaign.

Amara. (1999). Hebrew and English Borrowings in Palestinian Arabic in Israel: A Sociolinguistic study in Lexical integration and Diffusion. In Language and Society in The Middle East and North Africa: Studies in Variation and Identity, Yasir Suleiman (Ed.) Routledge. 
Bahumaid, S. (2015). Lexical Borrowing: The Case of English Loanwords in Hadhrami Arabic. International Journal of Language and Linguistics, 2(6), December 2015.

Dashti, A. (2015). The role and Status of the English Language in Kuwait. English Today, 31(3), September 2015, 28-33. https://doi.org/10.1017/s026607841500022x

Dashti, A. \& Dashti, F. (2015). EFL College Students' Attitudes towards Mobile Learning. International Education Studies, 8(8). https://doi.org/10.5539/ies.v8n8p13

Dashti, A. \& Dashti, F. (2016). Attitudes of Kuwaiti students towards English/Kuwaiti Arabic code switching in Kuwaiti Media. Arab Journal for the Humanities (AJH). Academic Publication Council, Kuwait University, 136, Autumn.

Davidson, Lisa., \& Noyer, R. (1996). Loan phonology in Huave: nativization and the ranking of faithfulness constraints. West Coast Conference on Formal Linguistics, 15(65), 7-9.

Filonik, S (2013). Gender Assignment to Loanwords in Ukrainian. In proceedings of the 2013 annual conference of the Canadian Linguistic Association.

Goldstein, D. (2011). The Use of English in Japanese Advertising. Unpublished undergraduate Honor thesis. Carnegie Mellon University.

$\begin{array}{lllll}\text { Gruppetta,.C (2016). } & \text { Language } & \text {-disabled-generation. } & \text { Retrieved } & \text { from }\end{array}$ http://www.timesofmalta.com/articles/view/20160722/opinion/a-language-disabled-generation.619576.

Hafez, O. (1996). Phonological and morphological integration of Loanwords into Egyptian Arabic. Premier Serie, Le langues en Egypt, NO, 27-28, 1996. https://doi.org/10.4000/ema.1958

Haugen, E. (1950). The analysis of linguistic borrowing. Language, 26, 210-231. https://doi.org/10.2307/410058

Heath, J. (1989). From Codeswitching to Borrowing: Foreign and Diglossic Mixing in Moroccan Arabic. London: Kegan Paul International.

Holes, C. (2015). Dialect, Culture, and Society in Eastern Arabic. Volume 111: Phonology, Morphology, Syntax, Style. Brill.

Holes, C. (1995). Modern Arabic. Longman. London and New York.

Holes, C. (1990). Gulf Arabic. London: Routledge.

Islam, R. A. (2011). The Morphology of Loanwords in Urdu: the Persian, Arabic and English Strands. PhD dissertation submitted to Newcastle University.

Jarrah, A. (3013). English Loan Words spoken by Madinah Hijazi Arabic Speakers. Arab World English Journal, AWEJ Special issue on Translation No. (2), 67-85.

Johnstone, T. M. (1967). Eastern Arabic Dialect Studies. New York, NY: Oxford University Press.

Kachru, B. (1994). 'Englishization and contact linguistics.' World Englishes, 13(2), 135-154. https://doi.org/10.1111/j.1467-971X.1994.tb00303.x

Kay, G. (1995). English loanwords in Japanese. Word Englishes, 14(1), 67-76. 1995. https://doi.org/10.1111/j.1467-971x.1995.tb00340.x

Kenstowicz, Michael. (2003). The role of perception in loanword phonology. A review of Les emprunts linguisiques d'origine europénne en Fon by Flavien Gbe to, Köln: Rüdiger Köppe

Verlag. (2000). Studies in African Linguistics, 32, 95-112.

Khan, A; Bukhari, N. H. (2011). Phonological Adaptation of English Loan Words in Pahari. Language in India; Jan2011, 11(1), 61.

La Charité, D \& Carole P. (2005). Category preservation and proximity versus phonetic approximationin loanword adaptation. Linguistic Inquiry, 36, 223-258.

Paradis, Carole \& Darlene LaCharité. (1997). Preservation and minimality in loanword adaptation. Journal of Linguistics, 33, 379-430

Ngom, F. (2006). Loanwords in the Senegalese Speech Community: Their Linguistics Features and Sociolinguistic Significance. Język, Komunikacja, Informacja P. Nowak, P. Nowakowski (red.) Language, Communication, Information P. Nowak, P. Nowakowski (eds) 1/2006. 
Tatsioka, Zio. (2008). Code-switching and English loanwords in the Greek media. In Newcastle Working Papers in Linguistics, 14(2008), 129-144

Oh, M. \& Kim, S. (2012). Morphological Effects in Loanword Adaptation: Adaptation of the English Plural Suffix into Korean. Linguistic Research, 29(2), 299-314. https://doi.org/10.17250/khisli.29.2.201208.002

Premawardhena, N. C. (2003). Impact of English loan words on modern Sinhala. 9th International Conference on Sri Lanka Studies. 28th - 30th November 2003, Matara, Sri Lanka.

Winter, F. E. (2008). "Studying Loanwords and Loanword Integration: Two Criteria of Conformity". Newcastle Working Papers, 14, 156-176.

\section{Appendix I}

\begin{tabular}{|c|c|c|c|}
\hline Number & Loanword & Meaning & Adaptation process \\
\hline 1. & /sna:bi/ & my snapchat & $\begin{array}{l}\text { Suffixing } 1^{\text {st }} \text { person } \\
\text { masculine/feminine singular } \\
\text { pronoun. }\end{array}$ \\
\hline 2. & /illsna:b/ & the snap & Prefixing KA definite article. \\
\hline 3. & $\begin{array}{l}\text { /fisna:bi/ } \\
\text { /bisna:bi/ }\end{array}$ & In my snabchat & $\begin{array}{l}\text { Prefixing KA Prepositions } \\
+ \text { suffixing } 1^{\text {st }} \text { person Singular } \\
\text { personal pronoun. }\end{array}$ \\
\hline 4. & /snab/ & Snapchat & Clipping \\
\hline 5. & /kalfarhum/ & their culture & $\begin{array}{l}\text { Suffixing } 3^{\text {rd }} \text { person singular } \\
\text { pronoun. }\end{array}$ \\
\hline 6. & /kaltgarna/ & our culture & $\begin{array}{l}\text { Suffixing 1st person plural } \\
\text { pronoun. }\end{array}$ \\
\hline 7. & /aka:wntha/ & her account & $\begin{array}{l}\text { Suffixing 3rd person singular } \\
\text { feminine personal pronoun. }\end{array}$ \\
\hline 8. & /aka:wnta:t/ & Accounts & $\begin{array}{l}\text { Changing a singular pronoun } \\
\text { into plural. }\end{array}$ \\
\hline 9. & /aka:wnti/ & my account & $\begin{array}{l}\text { Suffixing } 1^{\text {st }} \text { person Singular } \\
\text { masculine/ or feminine } \\
\text { personal pronoun. }\end{array}$ \\
\hline 10 & /aka:wnta/ & his account & $\begin{array}{l}\text { Suffixing 2nd person Singular } \\
\text { masculine personal pronoun. }\end{array}$ \\
\hline 11. & /aka:wnthom/ & their account & $\begin{array}{l}\text { Suffixing dual/ or plural } \\
\text { masculine/ or feminine } \\
\text { personal pronoun to a singular } \\
\text { English noun. }\end{array}$ \\
\hline 12. & /aka:wntathom/ & their accounts & $\begin{array}{l}\text { Suffixing dual/ or plural } \\
\text { masculine/ or feminine } \\
\text { personal pronoun to a plural } \\
\text { English noun. }\end{array}$ \\
\hline
\end{tabular}




\begin{tabular}{|c|c|c|c|}
\hline 13. & $/$ uu:zi/ & my shoes & $\begin{array}{l}\text { Suffixing } 1^{\text {st }} \text { person } \\
\text { masculine/feminine singular } \\
\text { pronoun. }\end{array}$ \\
\hline 14. & /îfu:z/ & the shoes & Prefixing KA definite article. \\
\hline 15. & /Ju:zha/ & her shoes & $\begin{array}{l}\text { Suffixing 2nd person } \\
\text { feminine singular } \\
\text { pronoun. }\end{array}$ \\
\hline 16. & /nikka/ & $\begin{array}{l}\text { His nickname } \\
\text { (in twitter) }\end{array}$ & $\begin{array}{l}\text { Suffixing 3rd person } \\
\text { masculine singular } \\
\text { pronoun + clipping }\end{array}$ \\
\hline 17. & /twi:tiri/ & my twitter & $\begin{array}{l}\text { Suffixing } 1^{\text {st }} \text { person } \\
\text { masculine/feminine singular } \\
\text { pronoun. }\end{array}$ \\
\hline Number & Loanword & Meaning & Adaptation process \\
\hline 18. & $\begin{array}{l}\text { /fitwi:tər/ } \\
\text { /bitwi:tər/ }\end{array}$ & in twitter & $\begin{array}{l}\text { Prefixing a prepositional } \\
\text { article. }\end{array}$ \\
\hline 19 & /litwi:təri/ & for my twitter & $\begin{array}{l}\text { Prefixing a prepositional } \\
\text { article }+ \text { Suffixing } 1^{\text {st }} \text { person } \\
\text { masculine/feminine singular } \\
\text { personal pronoun. }\end{array}$ \\
\hline 20. & /twi:tə/ & a tweet & $\begin{array}{l}\text { Suffixing KA indefinite } \\
\text { Article. }\end{array}$ \\
\hline 21. & /twi:ta:t/ & Tweets & $\begin{array}{l}\text { Changing a singular pronoun } \\
\text { into plural. }\end{array}$ \\
\hline 22. & /ritwi:ta:t/ & Retweets & Adapting English plural noun. \\
\hline 23. & $\begin{array}{l}\text { /la:tratwiit/ } \\
\text { /mu:tratwiit/ }\end{array}$ & Don't retweet & $\begin{array}{l}\text { Prefixing KA negative particle } \\
+ \text { changing the internal } \\
\text { structure of the verb. }\end{array}$ \\
\hline 24. & /ttajmla:jni/ & my timeline & $\begin{array}{l}\text { Suffixing } 1^{\text {st }} \text { person } \\
\text { masculine/feminine singular } \\
\text { pronoun. }\end{array}$ \\
\hline 25. & /ittajmla:jn/ & the timeline & Prefixing KA definite article. \\
\hline 26. & /ba:sworditf/ & your password & $\begin{array}{l}\text { Suffixing } 3^{\text {rd }} \text { person } \\
\text { feminine singular pronoun. }\end{array}$ \\
\hline 27. & /ba:swordi/ & my password & $\begin{array}{l}\text { Suffixing } 1^{\text {st }} \text { person } \\
\text { masculine/feminine singular } \\
\text { pronoun. }\end{array}$ \\
\hline 28. & /ilba:sword/ & the password & Prefixing KA definite article. \\
\hline
\end{tabular}




\begin{tabular}{|c|c|c|c|}
\hline 29. & /agwa:I/ & Goals & $\begin{array}{l}\text { Changing a singular noun into } \\
\text { Plural. }\end{array}$ \\
\hline 30. & //gawwa:It/ & I scored & $\begin{array}{l}\text { Conversion }+ \text { changing the } \\
\text { Internal structure of the noun }\end{array}$ \\
\hline 31. & /sku:1 ma:lik/ & your school & $\begin{array}{l}\text { Suffixing KA prepositional } \\
\text { Particle. }\end{array}$ \\
\hline 32 & /sikjoriti/ & Security & No change \\
\hline 33. & /bakeḑ/ & Package & $\begin{array}{l}\text { No change (except for } \\
\text { phoneme replacement) }\end{array}$ \\
\hline 34. & /ilgru:ba:t/ & the groups & $\begin{array}{l}\text { Prefixing KA definite article } \\
+ \text { changing a singular noun } \\
\text { into plural. }\end{array}$ \\
\hline 35. & /gru:ba:t/ & groups & $\begin{array}{l}\text { changing a singular noun } \\
\text { into plural. }\end{array}$ \\
\hline 36. & /gru:ba:ti/ & my groups & $\begin{array}{l}\text { changing a singular noun } \\
\text { into plural + Suffixing } 1^{\text {st }} \\
\text { person masculine/feminine } \\
\text { singular pronoun. }\end{array}$ \\
\hline Number & Loanword & Meaning & Adaptation process \\
\hline 37. & /gru:ba:tna/ & our groups & $\begin{array}{l}\text { Suffixing } 1^{\text {st }} \text { person masculine } \\
\text { /feminine plural pronoun. }\end{array}$ \\
\hline 38. & /gru:ba:tkom/ & your groups & $\begin{array}{l}\text { Suffixing } 2^{\text {st }} \text { person masculine } \\
\text { /feminine dual/plural pronoun. }\end{array}$ \\
\hline 39. & /gru:ba:thom/ & their groups & $\begin{array}{l}\text { Suffixing }{ }^{3 r d} \text { person masculine } \\
\text { /feminine dual/plural pronoun. }\end{array}$ \\
\hline 40. & /illofin/ & the lotion & Prefixing KA definite article \\
\hline 41. & /kabtfart & I captured & $\begin{array}{l}\text { Affixing the -ed inflectional } \\
\text { bound morpheme (a change in } \\
\text { the internal structure of the } \\
\text { verb). }\end{array}$ \\
\hline 42. & /lista:t/ & lists & $\begin{array}{l}\text { Changing the singular noun } \\
\text { into plural. }\end{array}$ \\
\hline 43. & /listə/ & one (fem) list & $\begin{array}{l}\text { Suffixing KA indefinite } \\
\text { Article. }\end{array}$ \\
\hline 44. & /illist $\mathbf{\partial} /$ & the list (fem) & Prefixing KA definite article. \\
\hline 45. & /illista:t/ & the lists & $\begin{array}{l}\text { Prefixing KA definite article } \\
+ \text { Changing the singular noun } \\
\text { into plural. }\end{array}$ \\
\hline 46. & $/$ sna:b/ & snapchat & $\begin{array}{l}\text { Clipping (phonological } \\
\text { phoneme replacement) }\end{array}$ \\
\hline
\end{tabular}




\begin{tabular}{|c|c|c|c|}
\hline 47. & /sna:bi/ & my snapchat & $\begin{array}{l}\text { Clipping + Suffixing } 1^{\text {st }} \\
\text { person masculine } \\
\text { /feminine plural pronoun. } \\
\text { (phonological phoneme } \\
\text { replacement) }\end{array}$ \\
\hline 48. & /sna:bha/ & her snapchat & $\begin{array}{l}\text { Clipping + Suffixing } 3^{\text {rd }} \\
\text { person feminine singular } \\
\text { pronoun. (phonological } \\
\text { phoneme replacement) }\end{array}$ \\
\hline 49. & /sna:bik/ & your snapchat & $\begin{array}{l}\text { Clipping }+ \text { Suffixing } 2^{\text {nd }} \\
\text { person masculine singular } \\
\text { pronoun. (phonological } \\
\text { Phoneme replacement) }\end{array}$ \\
\hline 50. & /sna:bitf/ & your snapchat & $\begin{array}{l}\text { Clipping }+ \text { Suffixing } 2^{\text {nd }} \\
\text { person feminine singular } \\
\text { pronoun. (phonological } \\
\text { Phoneme replacement) }\end{array}$ \\
\hline 51. & /sna:ba:ts/ & snapchats & $\begin{array}{l}\text { Clipping + changing singular } \\
\text { noun into plural. (phonological } \\
\text { Phoneme replacement) }\end{array}$ \\
\hline Number & Loanword & Meaning & Adaptation process \\
\hline 52. & /medzərfi:t/ & major sheet & No change \\
\hline 52. & medzor_i:ta:t/ & major sheets & $\begin{array}{l}\text { changing singular noun into } \\
\text { plural. }\end{array}$ \\
\hline 53. & /ilmedzər]i:t/ & the major sheets & $\begin{array}{l}\text { Prefixing KA definite article. } \\
+ \text { changing singular noun into } \\
\text { plural. }\end{array}$ \\
\hline 54. & /ilmedzərii:t/ & the major sheet & Prefixing KA definite article. \\
\hline 55. & /ba:rkin/ & parking & $\begin{array}{l}\text { No change (phonological } \\
\text { Phoneme replacement) }\end{array}$ \\
\hline 56. & /ilba:rkiy/ & the parking & Prefixing KA definite article. \\
\hline 57. & /gred/ & grade & No change \\
\hline 58. & /greda:t/ & grades & $\begin{array}{l}\text { changing singular noun into } \\
\text { plural. }\end{array}$ \\
\hline 59. & /ilgred/ & the grade & Prefixing KA definite article. \\
\hline 60. & /ilgreda:t/ & the grades & $\begin{array}{l}\text { Prefixing KA definite article. } \\
+ \text { changing singular noun into } \\
\text { plural. }\end{array}$ \\
\hline
\end{tabular}




\begin{tabular}{|l|l|l|l|}
\hline 61 & /greda:tə/ & his grades & $\begin{array}{l}\text { changing singular noun into } \\
\text { plural. + + Suffixing 3rd } \\
\text { person masculine singular } \\
\text { pronoun. }\end{array}$ \\
\hline 62. & $/$ greda:tha/ & her grades & $\begin{array}{l}\text { changing singular noun into } \\
\text { plural + Suffixing 3rd person } \\
\text { feminine singular pronoun. }\end{array}$ \\
\hline 63. & /sistim/ & system & No change \\
\hline 64. & /issistim/ & the system & Prefixing KA definite article. \\
\hline 65. & /sistimhom/ & their system & $\begin{array}{l}\text { Suffixing 3rd person plural } \\
\text { pronoun. }\end{array}$ \\
\hline 65. & /sistimhom/ & their system & $\begin{array}{l}\text { Suffixing 3rd person plural } \\
\text { pronoun. }\end{array}$ \\
\hline
\end{tabular}

\begin{tabular}{|c|c|c|c|}
\hline Number & Loanword & Meaning & Adaptation process \\
\hline 66. & /anfolo/ & unfollow & No change \\
\hline 67. & /dzornal/ & journal & No change \\
\hline 68. & /wi:kənd/ & weekend & No change \\
\hline 69. & /halwi:kənd/ & this weekend & Prefixing KA demonstrative. \\
\hline 70. & /rila:ks/ & relax & $\begin{array}{l}\text { Conversion (the verb used as } \\
\text { a noun) }\end{array}$ \\
\hline 71. & /səlfi/ & selfi & No change \\
\hline 72. & /hafta:g/ & hashtag & No change \\
\hline 73. & /il hafta:g/ & The hashtag & Prefixing KA definite article. \\
\hline 74. & /hal hafta:g/ & This hashtag & Prefixing KA definite article. \\
\hline 75. & /hafta:ga:t/ & hashtags & $\begin{array}{l}\text { changing singular noun into } \\
\text { plural changing singular noun } \\
\text { into plural }\end{array}$ \\
\hline 76. & /mənfin/ & mention & No change \\
\hline 77. & /latmənfini/ & Don't mention me & $\begin{array}{l}\text { Prefixing negative particle }+ \\
\text { Conversion (noun } \rightarrow \text { verb) }+ \\
\text { Suffixing } 1^{\text {st }} \text { person personal } \\
\text { Pronoun }\end{array}$ \\
\hline 78. & /ilmənfin/ & The mention & Prefixing KA definite article. \\
\hline 79. & /sta:f/ & staff & No change \\
\hline 80. & /sţa:f/ & staff & $\begin{array}{l}\text { Phonological phoneme } \\
\text { Replacement. }\end{array}$ \\
\hline 81. & /dawnta:wn/ & Down town & No change \\
\hline 82. & /iddawnta:wn/ & The down town & Prefixing KA definite article. \\
\hline 83. & /sofalmi:dja/ & Social media & No change + phonological \\
\hline
\end{tabular}




\begin{tabular}{|c|c|c|c|}
\hline & & & Vowel elision. \\
\hline 84. & /rawtər/ & Router & No change \\
\hline 85. & /ilrawtər/ & Router & Prefixing KA definite article. \\
\hline 86. & /rawtəra:t/ & Routers & $\begin{array}{l}\text { Changing singular noun into } \\
\text { plural }\end{array}$ \\
\hline 87. & /vojs/ & voice & No change \\
\hline 88. & /ilvojs/ & voice & Prefixing KA definite article \\
\hline 89. & /let/ & light & $\begin{array}{l}\text { No change + phonological } \\
\text { vowel replacement. }\end{array}$ \\
\hline 90. & /leta:t/ & lights & $\begin{array}{l}\text { Changing singular noun into } \\
\text { Plural + phonological } \\
\text { vowel replacement. }\end{array}$ \\
\hline 91. & /lokefin/ & location & No change \\
\hline 92. & /illlokefin/ & The location & Prefixing KA definite article. \\
\hline Number & Loanword & Meaning & Adaptation process \\
\hline 93. & /komənt/ & comment & No change \\
\hline 94. & /komənta:t/ & comments & $\begin{array}{l}\text { Changing singular noun into } \\
\text { Plural }\end{array}$ \\
\hline 95. & /ilkomənt/ & The comment & Prefixing KA definite article \\
\hline 96. & /ilkomənta:t/ & The comments & $\begin{array}{l}\text { Prefixing KA definite article } \\
+ \text { Changing singular noun into } \\
\text { Plural }\end{array}$ \\
\hline 97. & /komənta:thom/ & Their comments & $\begin{array}{l}\text { Changing singular noun into } \\
\text { plural + suffixing } 3^{\text {rd }} \text { person } \\
\text { plural personal pronoun. }\end{array}$ \\
\hline 98. & /ti:Sert/ & T-shirt & No change \\
\hline 99. & /itti:fert/ & The T-shirt & Prefixing KA definite article \\
\hline 100. & /ti:ferta:t/ & T-shirts & $\begin{array}{l}\text { Changing singular noun into } \\
\text { Plural }\end{array}$ \\
\hline 101. & /iti:ferta:t/ & The T-shirts & $\begin{array}{l}\text { Prefixing KA definite article } \\
+ \text { Changing singular noun into } \\
\text { Plural }\end{array}$ \\
\hline 102. & /ti:ferta:thom/ & Their T-shirts & $\begin{array}{l}\text { Changing singular noun into } \\
\text { plural + suffixing } 3^{\text {rd }} \text { person } \\
\text { plural personal pronoun. }\end{array}$ \\
\hline Number & Loanword & Meaning & Adaptation process \\
\hline 103. & /ma:sk/ & (face) mask & No change \\
\hline 104 & /ma:sks/ & (face) masks & $\begin{array}{l}\text { Changing singular noun into } \\
\text { Plural }\end{array}$ \\
\hline 105. & /ilma:sk/ & The (face) mask & Prefixing KA definite article \\
\hline
\end{tabular}




\begin{tabular}{|l|l|l|l|}
\hline 106. & /ilma:sks/ & The (face) masks & $\begin{array}{l}\text { Prefixing KA definite article } \\
+ \text { Changing singular noun into } \\
\text { Plural }\end{array}$ \\
\hline 107. & /bju:r/ & pure & $\begin{array}{l}\text { No change + phonological } \\
\text { consonant replacement. }\end{array}$ \\
\hline 108. & /kobibest/ & Copy paste & No change \\
\hline 109. & /ilkobibest/ & The copy paste & Prefixing KA definite article \\
\hline 110. & /bonas/ & bonus & No change \\
\hline 111. & /ilbonas/ & The bonus & Prefixing KA definite article \\
\hline 112. & $/$ blok/ & block & No change \\
\hline 113. & /nik/ & nickname & Clipping \\
\hline 114. & /nikik/ & $\begin{array}{l}\text { My nickname (my } \\
\text { Twitter account) }\end{array}$ & $\begin{array}{l}\text { Prefixing } \text { st }^{\text {st }} \text { person } \\
\text { singular personal pronoun. }\end{array}$ \\
\hline 115. & /kontenara:t/ & containers & $\begin{array}{l}\text { Changing singular noun into } \\
\text { Plural. }\end{array}$ \\
\hline 116. & & Special sauce & $\begin{array}{l}\text { No change + phonological } \\
\text { consonant replacement. }\end{array}$ \\
\hline
\end{tabular}

\begin{tabular}{|l|l|l|l|}
\hline Number & Loanword & Meaning & Adaptation process \\
\hline 117. & /ildzankfu:d/ & The junk food & Prefixing KA definite article \\
\hline 118. & /ilorganikfu:d/ & the organic food & Prefixing KA definite article \\
\hline 119. & /ilwa:jfa:j/ & The Wi-Fi & Prefixing KA definite article \\
\hline 120. & /intarnət & Internt & No change \\
\hline 121. & Kla:s/ & Class & No change \\
\hline 122. & /kla:sitf/ & your class & $\begin{array}{l}\text { Suffixing } 2^{\text {nd }} \text { person singular } \\
\text { feminine personal pronoun. }\end{array}$ \\
\hline 123. & /bilkors/ & in the course & $\begin{array}{l}\text { Prefixing prepositional } \\
\text { particle + KA definite article }\end{array}$ \\
\hline 124. & /fittlafizjon/ & in the TV & $\begin{array}{l}\text { Prefixing prepositional } \\
\text { particle + KA definite article } \\
+ \text { changing the internal } \\
\text { structure. }\end{array}$ \\
\hline 125. & & poster & No change \\
\hline 126. & /bostar/ & quality & No change \\
\hline 127. & /kwaliti/ & survey & $\begin{array}{l}\text { No change + phonological } \\
\text { consonant replacement. }\end{array}$ \\
\hline 128. & /serfe/ & minus & vowel replacement. \\
\hline
\end{tabular}




\begin{tabular}{|c|c|c|c|}
\hline 129. & /ilfa:jnal/ & the final (exam) & Prefixing KA definite article \\
\hline 130. & /inners/ & the nurse & Prefixing KA definite article \\
\hline 131. & $/ \mathrm{ka}: \int /$ & cash & No change \\
\hline 132. & /jikaji J/ & he cashes (money) & Phonological adaptation. \\
\hline 133. & /ha:kər/ & hacker & No change \\
\hline 134. & /ilha:kərz/ & the hackers & Prefixing KA definite article. \\
\hline 135. & /jiha:kkər/ & he hacks & Phonological adaptation. \\
\hline 136. & /o:lordi/ & already & No change \\
\hline 137. & /inistigra:mi/ & my Instagram & $\begin{array}{l}\text { Suffixing } 1^{\text {st }} \text { person singular } \\
\text { masculine/feminine personal } \\
\text { pronoun. }\end{array}$ \\
\hline 138. & /filinstigr:am/ & in the Instagram & $\begin{array}{l}\text { Prefixing prepositional } \\
\text { particle + KA definite article. }\end{array}$ \\
\hline 139. & /inistigra:ma:t/ & Instagrams & $\begin{array}{l}\text { Changing singular noun into } \\
\text { plural. }\end{array}$ \\
\hline 140. & /ilvidjo/ & the video & Prefixing KA definite article \\
\hline Number & Loanword & Meaning & Adaptation process \\
\hline 141. & /ilvidjowa:t/ & the videos & $\begin{array}{l}\text { Prefixing KA definite article } \\
+ \text { Changing singular noun into } \\
\text { plural. }\end{array}$ \\
\hline Number & Loanword & Meaning & Adaptation process \\
\hline 142. & /gru:ba:tilwats & $\begin{array}{l}\text { The WhatsApp } \\
\text { Groups. }\end{array}$ & $\begin{array}{l}\text { Changing singular noun into } \\
\text { plural + Prefixing KA definite } \\
\text { article + clipping }\end{array}$ \\
\hline 143. & /bra:jfit/ & private & $\begin{array}{l}\text { No change + phonological } \\
\text { consonant replacement). }\end{array}$ \\
\hline 144. & /ibabdet/ & with an update & $\begin{array}{l}\text { Prefixing prepositional } \\
\text { particle + deleting English } \\
\text { indefinite article }\end{array}$ \\
\hline 145 . & /la:jk/ & like (twitter term) & No change \\
\hline 146. & /ilfahros/ & the virus & $\begin{array}{l}\text { No change (+ phonological } \\
\text { consonant replacement) }\end{array}$ \\
\hline 147. & /ilmola:t/ & the malls & $\begin{array}{l}\text { Prefixing KA definite article } \\
+ \text { Changing singular noun into } \\
\text { plural. }\end{array}$ \\
\hline 148. & /ilkafeha:t/ & The coffee shops & $\begin{array}{l}\text { Prefixing KA definite article } \\
+ \text { Changing singular noun into } \\
\text { plural + change in internal } \\
\text { structure. }\end{array}$ \\
\hline
\end{tabular}




\begin{tabular}{|c|c|c|c|}
\hline 149. & /ablikefin/ & application & $\begin{array}{l}\text { No change + phonological } \\
\text { consonant replacement). }\end{array}$ \\
\hline 150. & /sos/ & Sause & No change \\
\hline 151. & /dip/ & dip & No change \\
\hline 152. & /dirikt/ & direct & No change \\
\hline 153. & /filba:jo/ & In the (twitter) bio & $\begin{array}{l}\text { Prefixing prepositional } \\
\text { particle + prefixing } \\
\text { indefinite article }\end{array}$ \\
\hline 154. & /brofa:j1/ & profile & $\begin{array}{l}\text { No change (+ phonological } \\
\text { consonant replacement). }\end{array}$ \\
\hline Number & Loanword & Meaning & Adaptation process \\
\hline 155. & /brofa:jli/ & my profile & $\begin{array}{l}\text { Suffixing } 1^{\text {st }} \text { person singular } \\
\text { masculine/feminine personal } \\
\text { pronoun. }\end{array}$ \\
\hline 156. & /ilmara $\theta$ on/ & the marathon & Prefixing KA definite article \\
\hline 157. & /ilrrisi:t/ & the receipt & Prefixing KA definite article \\
\hline 158. & /jitfajik/ & he checks & Phonological adaptation. \\
\hline Number & Loanword & Meaning & Adaptation process \\
\hline 159. & /mosidz/ & message & No change \\
\hline 160 & /məsidza:t/ & messages & $\begin{array}{l}\text { Changing singular noun into } \\
\text { plural }\end{array}$ \\
\hline
\end{tabular}

